\title{
Influence of low-tannin sorghum on performance and bone morphometrics of male Ross 308 broilers aged 1 - 42 days
}

\author{
T.G. Manyelo ${ }^{1}$, J.W. Ng'ambi $^{1}$, D. Norris ${ }^{1} \&$ M. Mabelebele ${ }^{2 \#}$ \\ ${ }^{1}$ University of Limpopo, Department of Agricultural Economics and Animal Production, School of Agricultural and \\ Environmental Sciences, Roodepoort, South Africa \\ ${ }^{2}$ University of South Africa, Department of Agriculture and Animal Health, College of Agriculture and Environmental \\ Sciences, Turfloop, South Africa
}

(Received 29 February 2019; Accepted 1 April 2019; First published online 22 May 2019)

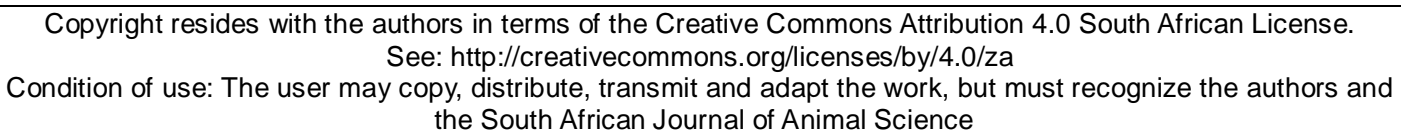

\begin{abstract}
The objective of this study was to determine the effects of low tannin sorghum as a maize replacement on the performance and bone morphometrics of Ross 308 broiler chickens. A total of 250 one-day-old broiler chickens were allotted to a complete randomized design with five treatments replicated five times. Birds were offered varying sorghum levels as maize replacement at $0 \%$ (control), 25\%, 50\%, 75\% and 100\%, formulated to be isonutritive and isoenergetic. The condensed tannin and total phenolic contents of the sorghum were analysed. Bodyweight and feed intake were measured weekly to calculate feed conversion ratio (FCR), and mortality was recorded as it occurred. Digestibility measurements were done when the chickens were between 15 and 21 days and between 35 and 42 days old. At ages 21 and 42 days, two chickens per pen were slaughtered to determine bone characteristics. A digital calliper was used to measure the length and diameter of the bones, and an electronic scale was used to determine the weight of the bones. Ash, calcium and phosphorus concentrations of the bones were determined. The Seedor and robusticity indices of the tibia were also calculated. The general linear model procedure of Statistical Analysis Software was used to analyse the data. At 1 - 21 days old bodyweight was higher for birds fed a level of 50\% sorghum than those that were offered the control diet. Replacing maize with sorghum improved the metabolizable energy (ME) of broiler chickens aged 42 days. Bodyweight and FCR of birds fed diets with $50 \%, 75 \%$ and $100 \%$ sorghum were higher and better, respectively, than those on diets with $25 \%$ and $0 \%$ sorghum at 22 - 42 days old. Bone morphometries of chickens aged 1 - 21 days and 22 - 42 days were not affected by replacing maize with sorghum. Thus, maize can be replaced by a low tannin white sorghum without causing adverse effects on chickens.
\end{abstract}

Keywords: minerals, tibia bone, Seedor and robusticity indices

\#Corresponding author: mabelebelem@gmail.com

\section{Introduction}

Maize is high in energy compared with other cereal grains and has multiple uses, but maize production requires higher water supply, so its use in drier areas, such as most of Africa, may be limited in the future (Travis et al., 2006). The inadequate and unpredictable production of maize and the intense competition among maize-based industries in South Africa have resulted in expensive poultry diets (Mabelebele et al., 2015). Alternative energy feed sources such as sorghum can be used for broiler diets to improve their productivity and reduce costs. These grains can be produced economically in relatively hot and dry climates, and can be used for human consumption and animal production (Sedghi et al., 2011). Compared with maize, sorghum is drought tolerant and can be grown successfully on relatively poor soils low in moisture. The ME and CP level of sorghum are $3270 \mathrm{kcal} / \mathrm{kg}$ and $9.5 \%$, respectively, which is comparable with $3319 \mathrm{kcal} / \mathrm{kg} \mathrm{ME}$ and $10.1 \% \mathrm{CP}$ content of maize (Nyamambi et al., 2007). The percentages of ash and fibre of sorghum are higher than those of maize. It has been documented that sorghum is relatively similar in cost to maize compared with other cereals such as wheat (Dicko et al., 2006). 
The whole sorghum grain consists of about $12 \%$ protein, $75 \%$ starch, $4 \%$ fat and $4 \%$ minerals compared with maize grain (Rajashekher et al., 2003). However, recommendations on the use of sorghum grain in broiler production are complicated because of the presence of condensed tannins, which result in poor feed efficiency in poultry. Plant breeders have developed better varieties over the years to reduce these limitations. The impact of new strains of sorghum on the productivity of chickens is not yet known. One example is the variety, Macia, which is a low-tannin sorghum variety discovered in Tanzania around 1997, as having a high drought tolerance and is likely to produce a crop even in years of less than average rainfall.

Macia is a white grained variety that contains low tannin. It has a grain size of $98.9 \mathrm{~mm}, 1000$ kernel weight of $20.3 \mathrm{~g}$ and grain textures of $52.5 \%$ (corneous), $40.0 \%$ (intermediate) and $7.5 \%$ floury. It has a protein content of 6.9 (nitrogen $\times 6.25 \mathrm{~g} / 100 \mathrm{~g}$ dry weight basis $(\mathrm{dwb})$ ), total phenols of $0.12 \mathrm{~g}$ catechin equivalents $/ 100 \mathrm{~g} \mathrm{dwb}$, and condensed tannin content of $0.01 \mathrm{~g}$ catechin equivalents $/ 100 \mathrm{~g} \mathrm{dwb}$ (Adetunji et al., 2013). It has been shown to be a good variety to be included in chicken diets because more than $1 \%$ condensed tannin in sorghum is regarded as high in poultry nutrition (Parthasarathy et al., 2005). Therefore, the objective of this experiment was to investigate the effect of replacing maize with the low-tannin white sorghum, Macia, on performance and bone morphometrics of male Ross 308 broiler chickens.

\section{Materials and Methods}

This study was conducted at the Animal Unit of the University of Limpopo, South Africa, in April and May 2016. The ambient temperatures around the study area ranged between $20^{\circ} \mathrm{C}$ and $36^{\circ} \mathrm{C}$ in summer and between $-5^{\circ} \mathrm{C}$ and $28^{\circ} \mathrm{C}$ in winter (Shiringani, 2007). The University of Limpopo lies at latitude $27.55^{\circ} \mathrm{S}$ and longitude $24.77^{\circ} \mathrm{E}$. It receives mean annual rainfall of less than $400 \mathrm{~mm}$ (Kutu \& Asiwe, 2010). The sorghum used in the study was a white Macia variety sourced from the Agricultural Research Council of South Africa in Potchefstroom, and was selected because of its colour and tannin content. After the sorghum had been harvested, the grains were field dried to less than $14 \%$ moisture content.

A total of 250 one-day-old male Ross 308 broiler chickens, weighing $42.1 \pm 3 \mathrm{~g}$, were randomly assigned to a complete randomized design with five treatments (sorghum levels) that were replicated five times with 10 birds per replicate. The sorghum replacement levels were $0 \%, 25 \%, 50 \%, 75 \%$ and $100 \%$, with diets formulated to be isonutritive and isoenergetic. The diets contained $16.5 \mathrm{MJ}$ energy/kg DM, 21.5\% CP, $17.5 \mathrm{MJ}$ energy/kg DM and 20\% CP (Tables 1 and 2) as recommended by NRC (1994) for chickens of 1 21 days and $22-42$ days old, respectively. The chickens were given feed and water ad libitum. Sorghum tannin content was determined according to the method of Price et al. (1978) and expressed as milligrams of catechin per $100 \mathrm{~g}$ sample. The total phenolic concentration of the sorghum was determined with the FolinCiocalteu assay (Singleton \& Rossi, 1965). Proximate analyses for ash, crude protein $(N \times 6.25)$ and fat were carried out according to the standard methods of AOAC (2012). Neutral detergent fibre (NDF) and acid detergent fibre (ADF) were established according to the methods of Van Soest et al. (1991). The Animal Ethics Committee of the University of Limpopo approved the experiment (number AREC/01/2017: PG). All management and procedures in this study were carried out in strict accordance with the requirements of the University of Limpopo Code of Practice for Experimental Animals. The initial bodyweights of the birds were taken with an electronic weighing scale at the beginning of the experiment and then at weekly intervals. Data on feed intake were measured by subtracting the weight of feed leftovers from that offered per day. Feed conversion ratio was calculated as the total amount of feed consumed divided by the weight gain of the chickens. Digestibility was done when the chickens were 21 and 42 days old. Digestibility was conducted in specially designed metabolism cages with separate watering and feeding troughs. Four birds were randomly selected from each replicate and transferred to the metabolism cages to measure apparent digestibility. A three-day acclimatization period was allowed prior to a three-day collection period. Droppings voided by each bird were collected daily at 09:00. Care was taken to avoid contamination from feathers, scales, debris and feed. Dry matter and nitrogen contents of the diets, refusals and faeces were determined (AOAC, 2012). The gross energy of the diets and excreta samples were determined with adiabatic bomb calorimetry. The apparent ME contents of the diets were calculated (AOAC 2012).

At the ages of 21 and 42 days, two chickens per pen were slaughtered by cervical dislocation in accordance with the regulations of University of Limpopo Animal Research Ethics Committee (AREC/01/2017:PG). A total of 80 right tibia from male Ross 308 broiler chickens of both ages were obtained and cleaned of the muscles by boiling them in deionized water for 10 minutes. For morphometric analysis, the bones were weighed $(\mathrm{g})$ with a precision scale (RADWAG, model PS 750/C/2). The length and width of the bones were determined using a measuring tape and a digital calliper (OMNI-TECH, SHA120). Tibia length was measured from the proximal end to the distal end and the width at the medial diaphysis. Then, the bones were dried at $100^{\circ} \mathrm{C}$ for 24 hours and weighed again. The bones were subsequently ashed at 600 ${ }^{\circ} \mathrm{C}$ overnight, cooled in a desiccator, and weighed. The ash was acid-digested by adding $1 \mathrm{~mL} 55 \%(\mathrm{v} / \mathrm{v})$ nitric acid $\left(\mathrm{HNO}_{3}\right)$. After cooling, calcium and phosphorus concentrations were determined (AOAC, 2012) 
using inductively coupled plasma spectroscopy. Geometric parameters (Seedor and robusticity indices) of the bones were determined and the thickness of the medial and lateral walls was measured at the midpoint mark using a dial calliper. The Seedor index was obtained by dividing the tibia weight by its length (Seedor et al., 1991). The robusticity index was determined with this formula (Reisenfeld, 1972):

$$
\text { Robusticity index = bone length/cube root of bone weight }
$$

Data on feed intake, bodyweight, FCR, digestibility, N-retention and tibia length, weight, diameter, ash, calcium phosphorus and bone geometric analysis were analysed using the general linear model (GLM) procedure of statistical analysis of variance (SAS, 2008).

Table 1 Ingredients and nutrient composition of the diets with varying sorghum inclusion level given to male Ross 308 broiler chickens aged 1 to 21 days

\begin{tabular}{lccccc}
\hline \multirow{2}{*}{ Feed Ingredient } & \multicolumn{5}{c}{ Sorghum levels (\%) } \\
\cline { 2 - 6 } & $\mathbf{0}$ & $\mathbf{2 5}$ & $\mathbf{5 0}$ & $\mathbf{7 5}$ & $\mathbf{1 0 0}$ \\
\hline Yellow maize (\%) & 57.9 & 43.4 & 29.0 & 14.5 & - \\
Sorghum (\%) & - & 14.5 & 29.0 & 43.4 & 57.9 \\
Soybean (\%) & 33.9 & 36.7 & 35.6 & 34.7 & 33.9 \\
Sunflower oil(\%) & 4.50 & 4.29 & 4.37 & 4.44 & 4.50 \\
Limestone (\%) & 1.09 & 1.09 & 1.09 & 1.09 & 1.09 \\
Dicalphosphate (\%) & 1.69 & 1.64 & 1.66 & 1.68 & 1.69 \\
Salt (\%) & 0.33 & 0.33 & 0.33 & 0.33 & 0.33 \\
Sodium bicarbonate (\%) & 0.001 & 0.001 & 0.001 & 0.001 & 0.001 \\
Vitamin + mineral premix ${ }^{\dagger}$ (\%) & 0.2 & 0.2 & 0.2 & 0.2 & 0.2 \\
DL-methionine (\%) & 0.16 & 0.15 & 0.16 & 0.16 & 0.16 \\
L-lysine (\%) & 0.18 & 0.12 & 0.15 & 0.16 & 0.18 \\
Total & 100 & 100 & 100 & 100 & 100 \\
Analysed nutrient composition & & & & & \\
Crude protein (\%) & 21.5 & 21.5 & 21.5 & 21.5 & 21.5 \\
Energy (MJ/kg DM) & 16.5 & 16.5 & 16.5 & 16.5 & 16.5 \\
Lysine (\%) & 1.15 & 1.15 & 1.15 & 1.08 & 1.15 \\
Methionine (\%) & 0.47 & 0.47 & 0.47 & 0.47 & 0.53 \\
Threonine (\%) & 0.66 & 0.68 & 0.67 & 0.66 & 0.89 \\
ADF (\%) & 9.86 & 8.38 & 9.09 & 13.84 & 16.65 \\
NDF (\%) & 24.39 & 24.75 & 24.89 & 26.31 & 29.15 \\
Fat (\%) & 3.58 & 3.94 & 4.01 & 4.34 & 5.19 \\
Ash (\%) & 5.72 & 5.75 & 6.54 & 5.97 & 6.62 \\
Ca (\%) & 1.00 & 1.00 & 1.00 & 1.00 & 1.00 \\
Condensed tannins ${ }^{\#}$ & $\mathrm{ND}$ & 0.03 & 0.06 & 0.09 & 0.12 \\
Total phenols ${ }^{\#}$ & $\mathrm{ND}$ & $\mathrm{ND}$ & $\mathrm{ND}$ & $\mathrm{ND}$ & 0.01 \\
& & & & & \\
\hline
\end{tabular}

\footnotetext{
\# Condensed tannins as percentage DM leucocyanidin equivalent

${ }^{\#}$ Expressed as tannic acid equivalent (\%); ND: not detected

${ }^{\dagger}$ The active ingredients in the vitamin-mineral premix were (per $\mathrm{kg}$ of diet) vitamin $\mathrm{A}: 12000 \mathrm{IU}$, vitamin $\mathrm{D}_{3}: 3500$ $\mathrm{IU}$, vitamin $\mathrm{E}: 30 \mathrm{mg}$, vitamin $\mathrm{K}_{3}: 2.0 \mathrm{mg}$, thiamine: $2 \mathrm{mg}$, riboflavin: $6 \mathrm{mg}$, pyridoxine: $5 \mathrm{mg}$, vitamin $\mathrm{B}_{12}: 0.02 \mathrm{mg}$, niacin: $50 \mathrm{mg}$, pantothenate: $12 \mathrm{mg}$, biotin: $0.01 \mathrm{mg}$, folic acid: $2 \mathrm{mg}$, Fe: $60 \mathrm{mg}, \mathrm{Zn}: 60 \mathrm{mg}, \mathrm{Mn}: 80 \mathrm{mg}, \mathrm{Cu}: 8 \mathrm{mg}$, Se: $0.1 \mathrm{mg}$, Mo: $1 \mathrm{mg}$, Co: $0.3 \mathrm{mg}$

NDF: neutral detergent fibre; ADF: acid detergent fibre; Ca: calcium
} 
Table 2 Ingredients and nutrient composition of the diets with varying sorghum inclusion level given to male Ross 308 broiler chickens aged (22 - 42 days)

\begin{tabular}{|c|c|c|c|c|c|}
\hline \multirow{2}{*}{ Feed Ingredient } & \multicolumn{5}{|c|}{ Sorghum levels (\%) } \\
\hline & 0 & 25 & 50 & 75 & 100 \\
\hline Yellow maize (\%) & 61.7 & 46.5 & 30.8 & 15.2 & - \\
\hline Sorghum (\%) & - & 15.2 & 30.8 & 46.5 & 61.7 \\
\hline Soybean (\%) & 31.0 & 33.7 & 32.8 & 31.6 & 31.0 \\
\hline Sunflower oil (\%) & 4.00 & 3.36 & 3.69 & 3.75 & 4.00 \\
\hline Limestone (\%) & 0.93 & 0.93 & 0.93 & 0.93 & 0.93 \\
\hline Dicalphosphate (\%) & 1.62 & 1.57 & 1.58 & 1.61 & 1.62 \\
\hline Salt (\%) & 0.35 & 0.35 & 0.35 & 0.35 & 0.35 \\
\hline Sodium bicarbonate (\%) & 0.001 & 0.001 & 0.001 & 0.001 & 0.001 \\
\hline Vitamins + minerals premix ${ }^{\dagger}(\%)$ & 0.13 & 0.13 & 0.13 & 0.13 & 0.13 \\
\hline DL-methionine (\%) & 0.15 & 0.14 & 0.15 & 0.15 & 0.15 \\
\hline L-lysine (\%) & 0.19 & 0.13 & 0.16 & 0.17 & 0.19 \\
\hline Total & 100 & 100 & 100 & 100 & 100 \\
\hline \multicolumn{6}{|l|}{ Analysed nutrient composition } \\
\hline Crude protein (\%) & 20.0 & 20.0 & 20.0 & 20.0 & 20.0 \\
\hline Energy (MJ/kg DM) & 17.5 & 17.5 & 17.5 & 17.5 & 17.5 \\
\hline Lysine (\%) & 1.17 & 1.17 & 1.17 & 1.10 & 1.17 \\
\hline Methionine (\%) & 0.49 & 0.49 & 0.49 & 0.49 & 0.55 \\
\hline Threonine (\%) & 0.68 & 0.68 & 0.68 & 0.70 & 0.91 \\
\hline ADF $(\%)$ & 8.38 & 8.11 & 9.42 & 12.44 & 13.69 \\
\hline NDF (\%) & 20.90 & 23.34 & 25.08 & 34.12 & 36.46 \\
\hline Fat (\%) & 3.68 & 4.28 & 4.70 & 5.07 & 5.11 \\
\hline Ash (\%) & 5.90 & 6.62 & 6.73 & 7.06 & 7.40 \\
\hline $\mathrm{Ca}(\%)$ & 0.82 & 0.82 & 0.82 & 0.82 & 0.82 \\
\hline Condensed tannins $^{\#}$ & ND & 0.03 & 0.06 & 0.09 & 0.12 \\
\hline Total phenols ${ }^{\#}$ & ND & ND & ND & ND & 0.01 \\
\hline
\end{tabular}

\footnotetext{
\# Condensed tannins as percentage catechin equivalent

\#\# Expressed as tannic acid equivalent (\%) ND: not detected

${ }^{+}$The active ingredients contained in the vitamin-mineral premix (per kg of diet) were vitamin A: 12 o00 IU, vitamin $\mathrm{D}_{3}: 3500 \mathrm{IU}$, vitamin $\mathrm{E}: 30 \mathrm{mg}$, vitamin $\mathrm{K}_{3}: 2.0 \mathrm{mg}$, thiamine: $2 \mathrm{mg}$, riboflavin: $6 \mathrm{mg}$, pyridoxine: $5 \mathrm{mg}$, vitamin $\mathrm{B}_{12}$ : $0.02 \mathrm{mg}$, niacin: $50 \mathrm{mg}$, pantothenate: $12 \mathrm{mg}$, biotin $0.01 \mathrm{mg}$, folic acid: $2 \mathrm{mg}$, Fe: $60 \mathrm{mg}, \mathrm{Zn:} 60 \mathrm{mg}, \mathrm{Mn}: 80 \mathrm{mg}$, Cu: $8 \mathrm{mg}$, Se: $0.1 \mathrm{mg}$, Mo: $1 \mathrm{mg}$, Co: $0.3 \mathrm{mg}$

NDF: neutral detergent fibre; ADF: acid detergent fibre; Ca: calcium
}

\section{Results and Discussion}

In the present study, white sorghum had higher levels of $\mathrm{CP}$, ash and fat than yellow maize meal. This is similar to observations by Ahmed et al. (2013), who reported that the CP level in sorghum meal was higher than in yellow maize. Yellow maize meal had higher ADF and NDF levels than sorghum meal. This is similar to the observation made by NRC (2012). No traces of tannins were found in yellow maize (Table 3). However, low levels of tannins were found in the sorghum in the present study and were similar to those reported by Adetunji et al. (2013) on the same sorghum line. The results of sorghum replacement level on performance measurements at the starter and grower phases are reported in Table 4. In the current study, sorghum replacement level did not affect $(P>0.05)$ feed intake, FCR and N-retention of broiler chickens aged 1 - 21 days. These findings are similar to those of Nyamambi et al. (2007), Ambula et al. (2001) and 
Table 3 Chemical composition (\%) of yellow maize and low-tannin sorghum (DM basis)

\begin{tabular}{lcc}
\hline Nutrient & Yellow maize & Low-tannin sorghum \\
\hline Crude protein & 11.70 & 13.03 \\
ADF & 5.30 & 3.59 \\
NDF & 4.21 & 2.94 \\
Ash & 1.79 & 2.67 \\
Fat & 4.23 & 2.79 \\
Starch & 50.1 & 54.6 \\
Condensed & ND & 0.12 \\
tannins & ND & 0.01 \\
Total phenols & & \\
\hline
\end{tabular}

ND: not detected; ADF: acid detergent fibre; NDF: neutral detergent fibre

Table 4 Influence of sorghum replacement levels on feed intake; bodyweight and feed conversion ratio, metabolizable energy intake and nitrogen retention of male broiler chickens aged 1 - 21 and 22 - 42 days old

\begin{tabular}{lcccccc}
\hline \multirow{2}{*}{ Variable } & \multicolumn{5}{c}{ Sorghum levels (\%) } & \multirow{2}{*}{ SEM } \\
\cline { 2 - 5 } & $\mathbf{0}$ & $\mathbf{2 5}$ & $\mathbf{5 0}$ & $\mathbf{7 5}$ & $\mathbf{1 0 0}$ & \\
\hline Starter (1 - 21 days) & & & & & & \\
Feed intake (g/bird) & 1107 & 1141 & 1131 & 1174 & 1171 & 21.657 \\
Bodyweight (g/bird) & $739^{\mathrm{b}}$ & $761^{\mathrm{ab}}$ & $791^{\mathrm{a}}$ & $783^{\mathrm{ab}}$ & $780^{\mathrm{ab}}$ & 15.688 \\
FCR & 1.49 & 1.50 & 1.43 & 1.50 & 1.50 & 0.0335 \\
ME (MJ/kg/bird) & $11.03^{\mathrm{b}}$ & $10.36^{\mathrm{c}}$ & $11.94^{\mathrm{a}}$ & $11.94^{\mathrm{a}}$ & $12.34^{\mathrm{a}}$ & 0.087 \\
N-retention (g/bird/day) & 1.17 & 1.28 & 1.15 & 0.95 & 0.87 & 0.077 \\
Grower (22 - 42 days) & & & & & & \\
Feed intake (g/bird) & 4340 & 4287 & 4319 & 4323 & 4334 & 28.330 \\
Bodyweight (g/bird) & $2411^{\mathrm{b}}$ & $2543^{\mathrm{b}}$ & $2760^{\mathrm{a}}$ & $2826^{\mathrm{a}}$ & $2920^{\mathrm{a}}$ & 67.718 \\
FCR & $1.80^{\mathrm{a}}$ & $1.69^{\mathrm{ab}}$ & $1.56 \mathrm{~b}^{\mathrm{c}}$ & $1.53^{\mathrm{c}}$ & $1.48^{\mathrm{c}}$ & 0.0445 \\
ME (MJ/kg/bird) & $11.22^{\mathrm{b}}$ & $10.67^{\mathrm{b}}$ & $11.30^{\mathrm{b}}$ & $12.30^{\mathrm{a}}$ & $12.72^{\mathrm{a}}$ & 0.173 \\
N-retention (g/bird/day) & 1.09 & 1.19 & 1.07 & 0.88 & 0.81 & 0.198 \\
\hline
\end{tabular}

a, b, c Means in the same row that do not share a common superscript are significantly different $(P<0.05)$

SEM: standard error of the mean

FCR: feed conversion ratio; ME: metabolisable energy; N-retention: nitrogen retention

Sonia et al. (2015), who observed that when replacing maize with sorghum there were no effects on feed intake and feed conversion ratio of broiler chickens aged 1 - 21 days. In addition, Torres et al. (2013) reported no significant differences in performance measurements among the treatments at 1 - 21 days old. Although bodyweight in the present study was higher $(P<0.05)$ for birds that were offered the sorghum replacement level of $50 \%$, Torab (2008) indicated that the bodyweight of broiler chickens fed up to $100 \%$ low-tannin content was higher than those on maize diets. These data agree with those of Sonia et al. (2015) and Torres et al. (2013, all of whom indicated no adverse effects of low-tannin sorghum on broiler performance. In the current study, sorghum replacement level at age 22 - 42 days did not affect $(P>0.05)$ the feed intake and $\mathrm{N}$-retention of broiler chickens. Replacing maize with sorghum improved the ME of broiler chickens aged 42 days. However, bodyweight and FCR of birds given 50\%, 75\% and 100\% sorghum were higher and better $(P<0.05)$, respectively, than those on $25 \%$ and $0 \%$. Contrary to these findings, Tandiang et al. (2014) reported that FCR and bodyweight were lower and higher for broiler chickens on maize and $100 \%$ low tannin sorghum-based diets, respectively. Torres at al. (2013) indicated that weight 
gain and FCR at 42 days old were better in birds fed a low sorghum diet than in those fed a high sorghum diet.

The results of tibia bone weight, length and diameter, and ash, calcium, phosphorus contents and bone geometric analysis of Ross 308 broiler chickens aged 1 - 21 days and 22 - 42 days are presented in Tables 5 and 6, respectively.

Table 5 Effect of replacing maize with sorghum on weight, length and diameter, and ash, calcium and phosphorus contents of right tibia bones of male Ross 308 broiler chickens aged 1 - 21 and 22 - 42 days

\begin{tabular}{|c|c|c|c|c|c|c|}
\hline \multirow{2}{*}{ Variable } & \multicolumn{5}{|c|}{ Sorghum levels (\%) } & \multirow{2}{*}{ SEM } \\
\hline & 0 & 25 & 50 & 75 & 100 & \\
\hline \multicolumn{7}{|c|}{ Starter (1 - 21 days) } \\
\hline Weight (g) & 6.48 & 6.23 & 5.70 & 6.47 & 6.45 & 0.373 \\
\hline Length (cm) & 4.48 & 4.33 & 4.10 & 4.27 & 4.38 & 0.106 \\
\hline Diameter (mm) & 4.20 & 3.30 & 3.90 & 3.93 & 3.80 & 0.227 \\
\hline Ash (\%) & 20.6 & 24.5 & 20.1 & 18.6 & 21.2 & 3.794 \\
\hline $\mathrm{Ca}(\mathrm{mg} / \mathrm{L})$ & 392.3 & 497.3 & 376.8 & 508.3 & 495.3 & 49.785 \\
\hline$P(m g / L)$ & 130.8 & 196.8 & 155.0 & 234.8 & 213.8 & 27.089 \\
\hline \multicolumn{7}{|c|}{ Grower (22 - 42 days) } \\
\hline Weight (g) & 14.00 & 14.33 & 13.06 & 14.44 & 13.54 & 0.553 \\
\hline Length (cm) & 9.59 & 9.50 & 9.13 & 9.44 & 9.31 & 0.137 \\
\hline Diameter (mm) & 8.90 & 8.69 & 8.96 & 8.64 & 9.12 & 0.328 \\
\hline Ash (\%) & 43.1 & 45.8 & 42.9 & 39.8 & 47.3 & 5.829 \\
\hline $\mathrm{Ca}(\mathrm{mg} / \mathrm{L})$ & 1337.5 & 1407.6 & 1182.5 & 1480.0 & 1292.5 & 97.664 \\
\hline$P(\mathrm{mg} / \mathrm{L})$ & 471.8 & 513.3 & 433.3 & 520.5 & 475.3 & 47.118 \\
\hline
\end{tabular}

SEM: standard error of means; Ca: calcium; P: phosphorus

Table 6 Effect of replacing maize with sorghum on tibia bone geometric analysis of male Ross 308 broiler chickens aged 1 - 21 days and 22 - 42 days

\begin{tabular}{|c|c|c|c|c|c|c|}
\hline \multirow{2}{*}{ Variable } & \multicolumn{5}{|c|}{ Sorghum levels (\%) } & \multirow{2}{*}{ SEM } \\
\hline & 0 & 25 & 50 & 75 & 100 & \\
\hline \multicolumn{7}{|l|}{ Starter (1 - 21 days) } \\
\hline Seedor index $(\mathrm{mg} / \mathrm{mm})$ & 2.40 & 2.35 & 2.30 & 2.32 & 2.36 & 0.049 \\
\hline Robusticity index & 1.45 & 1.44 & 1.39 & 1.48 & 1.47 & 0.073 \\
\hline \multicolumn{7}{|l|}{ Grower (22 - 42 days) } \\
\hline Seedor index (mg/mm) & 6.58 & 6.34 & 6.39 & 6.18 & 6.42 & 0.181 \\
\hline Robusticity index & 1.46 & 1.51 & 1.43 & 1.53 & 1.46 & 0.047 \\
\hline
\end{tabular}

SEM: standard error of the means

The results showed that replacing maize with a low-tannin white sorghum did not affect $(P>0.05)$ weight, length and diameter and ash, calcium, phosphorus contents and bone geometric analysis of Ross 308 broiler chickens. The current results are consistent with those of Chiripasi et al. (2013), who did not find significant differences in bone lengths and widths of broiler chickens fed sorghum-, millet- and maize-based diets. However, they are contrary to those of Chiripasi et al. (2013), who found a decrease in calcium and phosphorus contents of birds fed diets containing sorghum compared with those fed millet- or maize-based 
diets. Sorghum is known to contain anti-nutritional factors such as tannins and phytates, which reduce availability and utilization of minerals in poultry (Pinter et al., 2005). The present results are contrary to those of Moreki et al. (2011), who reported that tibia lengths in broiler chickens fed sorghum-based diets increased with an increase in sorghum inclusion. The current results on bone ash are contrary to those of Moreki \& Kelemogile (2012), who reported a decrease in bone ash in broilers fed sorghum-based diets. The authors indicated that a decline in bone ash could be associated with an increase in cereal grains (maize, millet and sorghum) in the diets of the birds, which tend to displace calories provided by other feed ingredients, thus disrupting the adequate nutritional balance, which affects bone growth and development.

\section{Conclusion}

It can be concluded that maize in the diets of broiler chickens aged 1 - 42 days can be replaced with a low-tannin white sorghum at 25\%,50\%, $75 \%$ and $100 \%$ levels without adverse effects on productivity and the bone morphometrics of the chickens. Thus, a combination of sorghum and other energy sources could enhance the effective utilization of sorghum in poultry feed. This augurs well for poultry farms in many rural areas of Africa where sorghum production is good.

\section{Acknowledgements}

The authors wish to acknowledge National Research Foundation (NRF) (grant number 94470) and VLIR-UOS (grant number ZIUS2016AP21) for financial support.

\section{Authors' Contributions} analysis.

TGM drafted the manuscript, JWN and MM conceptualised the research idea and DN conducted the statistical

\section{Conflict of Interest Declaration}

There authors declare that there is no conflict of interest.

\section{References}

Adetunji, A.I., Khoza, S., de Kock, H.L. \& Taylor, J.R.N., 2013. Influence of sorghum grain type on physico-chemical and sensory quality in a whole-grain and commercial enzyme mashing process. J. Inst. Brew. (wileyonlinelibrary.com) DOI 10.1002/jib.76.

Ahmed, M.A., Dousa, B.M. \& Atti, K.A.A., 2013. Effect of substituting yellow maize for sorghum on broiler performance. J. World's Poult. 3, 13-17.

Ambula, M.K., Oduho, G.W. \& Tuitoek, J.K., 2001. Effects of sorghum tannins, a tannin binder (Polyvinylpyrrolidone) and sorghum inclusion level on the performance of broiler chicks. Asian-Austral. J. Anim. Sci. 14, 1276-1281.

AOAC, 2012. Official methods of analysis. 18th edition. Association of Official Analytical Chemists, Arlington, Virginia, USA.

Chiripasi, S.C., Moreki, J.C., Nsoso, S.J. \& Letso, M., 2013. Effect of feeding yellow maize, white sorghum and pearl millet as energy sources on mineral intake, retention and utilization by guinea fowl under intensive management system. J. Sci. Technol. 3, 124-137.

Dicko, M.H., Gruppen, H., Traoré, A.S., Voragen, A.G.J. \& Van Berkel, W.J.H., 2006. Sorghum grain as human food in Africa: relevance of content of starch and amylase activities. Afr. J. Biotechnol. 5, 384-395.

Kutu, F.R. \& Asiwe, J.A.N., 2010. Assessment of maize and dry bean productivity under different intercrop systems and fertilization regimes. Afr. J. Agric. Res. 5 (13), 1627-1631.

Mabelebele, M., Siwela, M., Gous, R.M. \& Iji, P.A., 2015. Chemical composition and nutritive value of South African sorghum varieties as feed for broiler chickens. S. Afr. J. Anim. Sci. 45, 207-213.

Moreki, J.C. \& Kelemogile, K., 2012. Bone development in guinea fowl fed diets containing three cereal grains as sources of energy up to 12 weeks of age. J. Anim. Prod. Adv. 2 (8), 365-372.

Moreki, J.C., Van der Merwe, H.J. \& Hayes, J.P., 2011. Effect of dietary calcium intake on its retention by caged broiler breeder hens. Res. Opin. Anim. Vet. Sci. 1, 258-265.

NRC, 1994. Nutrient requirements of poultry. 9th revised edition. National Academy Press, Washington DC, USA.

Nyamambi, B., Ndlovu, L.R., Naik, Y.S. \& Kock, N.D., 2007. Intestinal growth and function of broiler chicks fed sorghumbased diets differing in condensed tannin levels. S. Afr. J. Anim. Sci. 37, 203-214.

Parthasarathy, P.R., Gurava, K.R., Reddy, V.S. \& Gowda, C.K., 2005. Linking producers and processors of sorghum for poultry feed. A case study from India. International Crops Research Institute for the Semi-Arid Tropics (ICRISAT), New Delhi, India. 12.

Pinter, J., Bujan, M., Homen, B., Gazic, K., Sikiric, M. \& Cerny, T., 2005. Effects of supplemental phytase on the mineral content in tibia of broilers fed different cereal-based diets. Czech J. Anim. Sci. 50, 68-73.

Pour-Reza, J. \& Edriss, M.A., 1997. Effects of dietary sorghum of different tannin concentrations and tallow supplementation on the performance of broiler chicks. Br. Poult. Sci. 38, 512-517.

Price, M.L., Van Scoyoc, S. \& Butler, L.G., 1978. A critical evaluation of the vanillin reaction as an assay for tannin in sorghum grain. J. Agric. Food Chem. 26, 1214-1218. 
Rajashekher, A.R., Prasad, V.L.K. \& Sudhakar, D., 2003. Sorghum and pearl millet for poultry feed. In: Alternate uses of sorghum and pearl millet in Asia. Common Fund for Commodities Technical Bulletin, 34. pp. 14-41. International Crops Research Institute for Semi-Arid Tropics, Patancheru, Andhra Pradesh, India.

Reisenfeld, A., 1972. Metatarsal robusticity in bipedal rats. Am. J. Phys. Anthropol. 40, 229-234.

SAS. 2008. SAS User's Guide Version 9.2. 2nd Edition. SAS Institute, Inc. Raleigh, North Carolina, USA.

Sedghi, M., Ebadi, M.R., Golian, A. \& Ahmadi, H., 2011. Estimation and modelling true metabolizable energy of sorghum grain for poultry. Poult. Sci. 90, 1138-1143.

Seedor, J.G., Quarruccio, H.A. \& Thompson, D.D., 1991. The bisphosphonate alendronate (MK-217) inhibits bone loss due to ovariectomy in rats. J. Bone Miner. Res. 6, 339-346.

Shiringani, R.P., 2007. Effect of planting date and location on phenology, yield and yield components among selected cowpea varieties. Master's dissertation. University of Limpopo, South Africa. pp. 20-73.

Singleton, V.L. \& Rossi, J.A., 1965. Colorimetry of total phenolics with phosphomolybdic-phosphotungstic acid reagents. Am. J. Enol. Vitic. 16, 144-158.

Sonia, Y.L., Fox, G., Khoddami, A., Neilson, K.A. Truong, H.H., Moss, A.F. \& Selle, P.H., 2015. Grain sorghum: A conundrum for chicken-meat production. Agriculture 5, 1224-1251.

Tandiang, D.M., Diop, M.T., Dieng, A., Yoda, G.M.L., Cisse, N. \& Nassim, M., 2014. Effect of corn substitution by sorghum grain with low tannin content on broilers production: Animal performance, nutrient digestibility and carcass characteristics. Int. J. Poult. Sci. 13, 568-574.

Torab, A.M., 2008. Comparative studies to evaluate the nutritive value of feterita, white and yellow maize in broiler diets. MSc thesis. College of Agricultural Studies, Sudan University of Science and Technology, Khartoum.

Torres, K.A.A., Pizauro Jr, J.M., Soares, C.P., Silva, T.G.A., Nogueira, W.C.L., Campos, D.M.B., Furlan, R.L. \& Macari, M., 2013. Effects of corn replacement by sorghum in broiler diets on performance and intestinal mucosa integrity. Poult. Sci. 92, 1564-1571.

Travis, D.K., Tuinstro, M.R. \& Hancock, J.D., 2006. Variation in nutritional value of sorghum hybrids with contrasting seed weight characteristics and comparisons with maize in broiler chicks. Crop Sci. 46, 695-699.

Van Soest, P.J., Robertson, J.B. \& Lewis, B.A., 1991. Methods for dietary fiber, neutral detergent fiber, and non-starch polysaccharides in relation to animal nutrition. J. Dairy Sci. 74, 3583-3597. 